\title{
TAFSÎR ON JIHAD VERSES IN AKU MELAWAN TERORIS: Relevance Measurement in The Perspective of Fakhr Dîn al-Râzî
}

\author{
Ali Hamdan
}

Universitas Islam Negeri Maulana Malik Ibrahim Malang, Indonesia

E-mail: hamdan@syariah.uin-malang.ac.id

\section{Abstract}

A discourse on the justification of radical act faked as jihad based on Fakhr al-Din al-Râzî's perspective is the cause of this study. The question is "How is al-Râzîs opinion on verses used to justify radical acts which are faked as jihad?" This study uses the perspective of Fakhr al-Dîn al-Râzî's Tafsîr bi alRa'yi. It is library research employing a qualitative explorative paradigm. All data are in the form of documentation; primary data are from Mafâtih alGhayb and book entitled Aku Melawan Teroris as well as other secondary data. The study shows, first: jihad and its meaning are relevant to the period of Quran revelation to date and theologically they will also be relevant in the future; nothing changes from jihad's concept and substance except the situation and condition. Second, there are five verses in Quran becoming the justification basis of radical acts in the name of jihad i.e., Q.S. al-Tawbah [9]: 5, Q.S. al-Tawbah [9]: 14, Q.S. al-Tawbah [9]: 36, Q.S. Anfâl [8]: 39, and Q.S. al-Baqarah [2]: 191; yet it is contra-productive for al-Râzî. Through this study, al-Râzî's tafsîr model is expected to be a formula and new opinion to deeply comprehend, contextual wise, the meaning of those verses.

Kajian ini muncul dari adanya wacana pembenaran terhadap tindakan radikal dengan dalih jihad melalui perspektif Fakhr al-Dîn al-Râzî, 
pertanyaan yang ingin dijawab dalam kajian ini adalah: "bagaimana pandangan al-Râzî terhadap ayat-ayat yang menjadi argumentasi pembenaran terhadap tindakan radikal dengan dalih jihad?" Kajian ini menggunakan perspektif tafsir bi al-ra'yî ala Fakhr al-Dîn al-Râzî́; jenis studi pustaka, menggunakan paradigma kualitatif eksploratif; keseluruhan datanya berbentuk dokumentasi dengan bahan primer Mafâtîh al-Ghayb dan buku Aku Melawan Teroris, dengan didukung bahan-bahan sekunder tertulis yang lain. Kajian ini menunjukkan beberapa hal, pertama: jihad dan segala maknanya relevan dengan masa turunnya Al-Qur'an hingga sekarang dan secara teologis juga relevan hingga masa yang akan datang; tidak ada yang berubah dari konsep dan substansi jihad kecuali situasi dan kondisinya. Kedua, terdapat lima ayat Al-Qur'an yang dijadikan justifikasi pembenaran terhadap tindakan radikal atas nama jihad, yaitu Q.S. alTawbah [9]: 5, Q.S. al-Tawbah [9]: 14, Q.S al-Tawbah [9]: 36, Q.S. Anfâl [8]: 39, and Q.S. al-Baqarah [2]: 191; namun bagi al-Râzî justru kontraproduktif. Melalui kajian ini. model penafsiran al-Râzî diharapkan dapat menjadi formula dan pandangan baru dalam memahami lebih dalam dan kontekstual akan makna dari ayat-ayat tersebut.

Keywords: Imam Samudra; jihad; Mafâtîh al-Ghayb; al-Râzî; tafsir bi al-ra'ŷ̀

Received: January 6, 2020; Accepted: June 15, 2020

\section{Introduction}

Aku Melawan Teroris is the work of Imam Samudra, the death-row convict of the Bali bombing. This book is a medium to share his heart and mind out, his belief, his argumentation and justification about his act which was considered radical. It contains Quran verses that are comprehended textually without using authoritative tafsîr reference to comprehensively understand those verses. Published by Jazeera in 2004, this book can still be found to date since two online shopping websites sell it. Some links also sell it through the internet and can be downloaded in PDF format after doing the transaction via credit card.

Quran verses which become the justification basis on the radical acts in Aku Melawan Teroris are blown up again in Nasir Jamil's book entitled Membongkar Jamaah Islamiyyah: Pengakuan Mantan Anggota JI and 
was published by Grafindo in 2005. The latter contains the author's objection to Imam Samudra's argumentation (Jamil 2005, 108-9), yet this relies only on his knowledge and not on authoritative tafsîr literatures.

Although both books have been published for several years and their doctrines, as well as argumentation, are considered out-of-date, they still affect the readers and new fans. This fact significantly has a negative impact. It is proven by the existence of links from Google about these books in the form of viewer and reader that add up more and more as time goes. Definitely, the links contain many different things such as discussion, research, curiosity, or even admiration and heroic obsession.

Tafsîr discussion in Indonesia has yet been about verses which are the basis of justification argumentation on radical acts i.e., Quran verses understood textually (Nizar 2015). Mainly, it is related to tafsîr model contained explicitly in Aku Melawan Teroris. However, generally, all tafsîr literatures from the classic to contemporary ones with various types and methodologies indeed contain tafsîr of those verses.

Fakhr al-Dîn al-Râzî (d. 606 H) is an authoritative mufassir (author of tafsîr) proven by his well-known work Mafâtîh al-Ghayb which is acknowledged and becomes the reference in Islam to date. Al-Dhahabî stated Mafâtîh al-Ghayb is admitted by ulama (Islamic scholar) because it has a very distinctive character compared to other tafsîr literatures; its discussion is broader covered the various background of knowledge (al-Dhahabî n.d., 208; Mahmud 2006, 320). Besides, his work becomes an advanced study for the researchers of tafsir literatures in the Islam world. There is a scientific work that specifically discussed the methodology of this tafsir book and concluded that the perspective of this tafsîr is loaded with kalâm aspect, linguistics, and formal legal/fiqh, philosophy, tasawuf (Sufism), and Aristotelian's logic (Khalid 2018, 97-115).

Looking at the above argument, it is right and essential to say that every problem should be placed in its portion. In this case, we place the verses used for justification argumentation on radical acts into tafsîr portion and authoritative interpretation. All well-known tafsîr literatures in Islam with a brief and broad explanation are categorized authoritative. However, Fakhr al-Dîn al-Râzî discusses Quran verses tafsîr in different forms i.e., multi-discipline and knowledge as well as using reason and range of interpretation highly acknowledged by his peers. 
One urgent theme that has been discussed many times before, is about jihad, radicalism and tafsîr of Mafâtîh al-Ghayb is Islam dan Radikalisme: Telaah atas Ayat-Ayat Kekerasan dalam al Quran by Dede Rodin. The focus of this discussion is reviewing the history of jihâd (fight) and qitâl (war) verses to be comprehensively understood. The fundamental difference between jihad and radicalism is also the main point of this discussion (Rodin 2016). Penafsiran Ayat-Ayat Pemicu Radikalisme Perspektif Ibn Taimiah dan Quraish Shihab (Telaah Q.S At-Taubah (9): 5 dan 29) is also the related literature written by Siti Khairunnisa et. al. They reviewed Ibnu Taymiah and Quraish Shihab's perspectives on Q.S. al-Tawbah [9]: 5 and 29 (Khairunnisa, Zain, and Muthi'ah 2016). Junaidi Abdillah discussed Radikalisme Agama: Dekonstruksi Ayat-Ayat "Kekerasan" dalam al-Quran. He focused on the use of religion behind radicalism and deconstruction of tafsîr verses, which are suspected of triggering radicalism (Abdillah 2014).

Furthermore, some previous studies related to Fakhr al-Dîn al-Râzî or his tafsîr book are; first, Konsep Pendidikan Sains Menurut al-Râzî (Telaah terhadap Tafsir Mafâtîh al-Ghayb) written by Muhammad Azhari. This study explored Islam science theory and its relevance to modern science. He also stated that science must incline to Allah Almighty's oneness (Azhari 2013). Second, there was a study entitled Ketenangan Jiwa Menurut Fakh al-Din alRâzi dalam Tafsîr Mafâtîh al-Ghayb as a response to WHO's data in 2002 that 150 million people suffered in depression. Al-Râzî claimed that the cause of depression is khawf, khuzn, hulu', hubbb al-dunyâ, hasad, tafâkhur and takâthur (Jalaluddin 2018). Another study entitled Metodologi Tafsir Fakhru al-Din alRazi, Telaah Tafsir QS Al-Fatihah dalam Mafatih al-Ghayb written by Anas Shafwan Khalid which was intensely focused on the methodological study in this tafsîr book (Khalid 2018).

After looking through the aforementioned previous studies, the author concludes that this current study object has not been discussed before. There were already some studies about radicalism; Dede Rodin discussed Jihad and Radicalism, Siti Khoirunnisa talked about tafsîr verses triggering radicalism based on Ibnu Taymiah's perspective, and Junaidi Abdillah discussed the deconstruction of violence-content verses in Quran. Those make verses on jihad justification in Aku Melawan Teroris never been an object of their studies; furthermore, Fakhr al-Dîn al-Râzî's tafsîr bi al-ra'ŷ̀ is taken into account. Previous studies on Fakhr al-Dîn al-Râzî and his tafsîr book Mafâtîh al-Ghayb also focused on the thematic and methodological 
discussion which are not related to the current study object at all i.e., verses on jihad justification.

Based on those reasons, this study is meant to fill the gap in the previous studies. Specifically, the main question is "How is al-Râzî's perspective on verses that become the justification argumentation of radical acts which were faked as jihad?" This question is considered necessary because of an exaggerated implementation about jihad leading to radical act and affecting severely to the unity of the country and the religious life.

The current study uses descriptive explorative analysis. It is included in qualitative study, specifically in library research category since its primary data is the book Aku Melawan Teroris written by Imam Samudra and Mafâtîh al-Ghayb supported by other secondary written data. Moreover, this study is a significant attempt in holistically viewing the development of Quran study, precisely on jihad and the misused understanding toward God's verses, mainly in Indonesian context.

\section{Jihad and Radicalism: Definition and Implementation}

Jihad in a simple definition as explained by al-Qurțubî is badhlu alwasî̀ (al-Qurtubî 1964, 50) i.e. mustering up all capabilities. According to Ibn Hajar, jihad is al-mashaqqah which means "difficulty" or "tiredness" (al"Asqalânî 1379 H, 3). Based on the opinion of both grand imâm (leader), jihad can be defined as "struggling by mustering up capability in confronting the condition and difficulty". This concept is in line with the Prophet Muhammad PBUH's explanation when someone asked permission to do jihad; the Prophets asked if his parents are still alive. The person answered yes. Then, the Prophet ordered him to 'jihad' to his parents (alBukhârî 1422 H, 59). In a different situation, the Prophet once said "Afdal al-jihâd hajj mabrûr" (al-Bukhârî $1422 \mathrm{H}$, 133). This narration can be analogized that hajj and jihad have a similar level of difficulty and intricacy in its implementation.

In another perspective, jihad is interpreted as "battling against enemy". It also means to maximally try and muster up capability and energy in the form of statement, action, and strategy. Quran verses and hadith text support this perspective. Quran explains, "Wa in jâhadaka 'alâ an tushrika bî mâ laysa laka bihî 'ilm falâ tuti'humâ" (Q.S. Luqmân [31]: 15), and "Wa alladhîna jâhad̂̂ finâ lanahdiyannahum subulanâ" (Q.S. al-'Ankabût [29]: 69). 
The word "jihâd" in both verses is apprehended as "mustering up all capabilities and also energies".

Whereas in hadith, the word is understood as al-qitâl (war). It can be seen from companion's question to the Prophet PBUH in a very long hadith, "Ma al-jihâd? Qâla: An tuqâtila al-kuffâra idhâ laqîtum" (al-Shaybânî n.d., 252). This hadith content asserted that jihad has a similar benefit and virtue with other kinds of worship e.g. salâh (prayer) and sawm (fasting); however, we should note that the word jihad in that hadith is the one with war and not the one with restraining lust.

When the word jihad is constructed with the two main words Jihâd fì Sabîl Allâh interpreted as jihad in the path of Allah the Almighty, then the meaning drastically changes. In a more theoretical definition, Ibn Taymiah explains that, terminologically, Jihad fî Sabîl Allâh has a broader sense. It covers every power and effort to help the justification that has been regulated by Allah and to ignore falsehood by using the existing potential in the forms of action, statement, and heart, as well as wealth and soul (alHurânî 1987, 608). Manșûr al-Bahûtî adds that the existing potentials are used by doing the command to battle directly (al-Bahûtî n.d., 36).

Further explanation on Jihad fî Sabîl Allâh, Ibn Taymiah states that one of implementations of jihad is by using hands such as hitting, stabbing, throwing, and preparing properly. Yet, there are times when it is only implemented orally, i.e. doing Islamic preaching in Allah the Almighty's path, repelling the attack toward the doubts of His sharia and conducting deliberation. Besides, jihad can be done by heart such as being consistent and always managing heart toward God. It can also be in the form of expectation and pray to mujâhidin (fighters) that they will win against the enemies. Jihad is the activity that completes one another, yet doing jihad with hands is the highest level. Those three activities are categorized as jihad and the one implementing it is called mujâhid (al-Hurânî 1987, 608).

According to Seyyed Hossein Nasr, there are around 36 qitâl and jihad verses in Quran; approximately 39 words of ja-ha-da are in different derivations. However, in quantity, no more than ten verses are related to battle (Nasr 2003, 313-4). Dede Rodin reveals that the rest referred to daily activities both physically and mentally and the earnest attempt to bring God's justice on earth, the noble moral values development and maintaining justice and peace as well as prosperity for all people (Rodin 2016). Quran verses containing the word jihad raise an understanding that 
every jihad word in each verse has various contexts, yet still focusing on the purpose to realize peace, prosperity, justice, and the improvement of soul and physic quality.

\section{Radicalism: from Textual Understanding to Action}

Islamic fundamental teachings are shahada, șalâh (worship), zakâh (alm), fasting, and hajj (for those who can afford it). The Quran and sunnah of the Prophet Muhammad PBUH, which are the primary sources of Islamic life, have never actually expressed radicalism in any of forms and objects. However, in understanding some of the verses that are related to jihad and war in the Quran, people tend to only understand its textual meaning. It is done without any concern for the historical and sociological aspects as well as the implementation of Islamic life of the Prophet Muhammad. Perfecting the akhlâq/morals of humans across ethnicities, nations, faiths, and even groups have become the mission of the Prophet Muhammad. The verses mention it as a blessing for the universe.

Radical understanding (al-mutatarruf) and radicalization (al-tatarruf) are terminologies that contain controversies, just like the term 'terrorist' (alirhâb). Eastern and Western academicians have their definitions for globally radical movement according to their perspectives. However, both parties agreed on the objective of radical actions that lead to political violence, terror, and extremeness. The word "radical" in Indonesian has three meanings: first, thorough, totally, and change; second, strongly demanding a change; and third, advance in both thinking and action (Dinas Pendidikan 1990, 718). In a theoretical definition, Dhiyab and al-Hasan emphasize that radical is "a process of adopting extreme system and value as changes, acceptance, help or abuse, and a sugar-coated promise occurred as the ways to put the changes into reality, within the society, or encourage individuals or groups to do the same" (Dhiyab and al-Hasan 2017, 3-6).

Understanding the aforementioned theoretical definition of radicalism, it is genuinely a connected and organized activity that believes in the use of powers and weapons to interact. Believes in jihad become the only way to be progressive and to fight over something, concentrates on religious, political, and social issues and excommunicates those who have different understanding or belief. These ways that are implemented radically have then been known as radicalism. Its main characteristics are 'a claim of a single truth', misdirection of any community that is not on par, a 
kâfir/non-believer justification towards non-members, an exaggerated and improper act of religious rituals, suspicion against non-community, rough attitude in interaction, being loud in speaking, and being emotional in preaching. Changes in society, politics, system or regime are hidden aspiration, and it becomes a robust doctrine for the implementation of radical actions.

These radical actions are depicted from the reality that frequently occurred in form of violent actions done by some Islamic groups while implementing Islamic teachings (Umam 2019). Thus, a new negative terminology appears that is Radical Islam. Khamami Zada delivers a further explanation about it by quoting Horace M. Kallen's theory that Radical Islam is totally and comprehensively fighting for Islam, demanding Islamic sharia to be the foundation of the state and Islam as the political system. Moreover, Zada explicates that the old generation (salaf) has become an exemplary Muslims in doing religious activities who went against all Western products such as modernization and secularization, and eventually fought against any movement that was assumed as a part of liberalization against Islam (Zada 2011, 16).

\section{Intellectuality of Fakhr al-Dîn al-Râzî}

Fakhr al-Dîn al-Râzî is a Muslim scholar, a charismatic ulama, and also a traveler. Other Muslim scholars have considered him as a faqîh (an expert in fiqh science), al-Hâkim (wise), al-Adîb (literati), al-Mutakallim (an expert in aqeedah and philosophy) and of course a traveler (al-Hamawî $1414 \mathrm{H}, 2582)$. The highest title or laqab bestowed to him is Shaykh al-Islâm (Nuwayhad 1409 H, 596).

The complete name and nasab (lineage) of this big Imâm (Islamic leadership position) is Muhammad ibn 'Umar ibn al-Hasan ibn al-Husayn ibn 'Alî al-Taymî al-Bakrî al-Ṭabrastânî (Ibn Khallikân 1904, 249). Yâqût alHamawî (d. 626 H) said that he is also an al-Quraysh (al-Hamawî 1414 H, 2585) that illustrates one of his lineage that is Quraysh, the most prominent tribe in pre and post Islam occurrence in Mecca. Âdil Nuwayhad elucidates the detail of Quraysh nasab that he is the descendant of Abû Bakr alShiddîq (Nuwayhạ 1409 H, 596).

Fakhr al-Dîn al-Râzî is also a noble scholar who is honored, a dignified person, and a polite person who keeps his self-esteem. He has a perfect physical feature that is a proportional body based on humans' 
average standards at that time (Bamakhramah $1428 \mathrm{H}, 25)$. Yâqût alHamawî mentions that the numbers of people who accompanied him on a trip could reach more than three hundred people. Those are his students who are fuqahâ (one who has fulfilled the conditions for ijtihâd), mutakallim (scholastic theologians of Islam), ușûlî, mufassir (a person who wishes to interpret the Quran), those who work in medical field and others (alHamawî 1414 H, 2585). The Islamic world appreciated his teachings that reached out to all groups or communities at that time. It is not surprising if all kinds of community and levels of society across madhhabs/schools of thought attended his academy of science to have discussions on various things (al-Hamawî 1414 H, 2585). Tâj al-Dîn al-Subkî (d. 771 H) praised him by addressing him as imâm al-mutakallimin (the leader of science of discourse) and acknowledged his accurate elaboration skills in science and society (al-Subkî 1413 H, 81). Al-Ziriklî (d. 1396 H) called him imâm mufassir (the leader of interpreter). He was the only ulama who has an ability in contextual and textual understanding in his era (al-Ziriklî 2002, 313).

Fakhr al-Dîn al-Râzî is also well-known as a scientist and intellectual in various fields of study. It is reflected from the masterpieces spread to all Islamic countries, and the society has a massive enthusiasm in responding to this. His documented masterpiece such as al-Tafsîr al-Kabîr, or is known as Mafâtîh al-Ghayb in tafsîr study (interpretation) consists of twenty-five chapters and topics solely about al-Fâtihah; it could reach one significant chapter (Ibn Khallikân 1904, 249).

\section{Legal Standing Verses Claiming the Truth and Radical Argumentation}

Some individuals have radical patterns of thinking and reinforcement by using the verses of Quran in the movement that is striven for argumentation or justification towards legal actions (in their point of view) that have been performed. Some of the Quran verses, which are the cause of the argumentation of the truth, are found in form of written verses as conveyed in the reinforcement and routine Quran recitation in groups. Some are found in form of written documentation that is book.

Aku Melawan Teroris is the book that documented the verses of Quran as the argument of justification towards Imam Samudra's action. He was a convict of the bomb incident in Bali who was guilty as charged and was executed in 2014 (Royds, Lewis, and Taylor 2005). The national medias 
have fully covered the news, and it can still be accessed in the internet today. Various memes with positive and negative tone are spread in social media and can still be accessed on the internet. It can't be denied that Indonesian Muslim community have seen this case differently, either as a matter of heroism or radicalism.

The verses of the Quran used as the proposition of justification towards their actions, as written in the book, are the effects of textual understanding without the efforts to employ the authoritative literatures of Quran interpretation/tafsir as the medium to understand the verses comprehensively. If it was appropriately used, the more in-depth understanding and more tolerant action will come to the surface. The verses used by Imam Samudra as both argumentation and justification of truth toward his actions (Samudra 2004, 107-16) are: Q.S. al-Tawbah [9]: 5 that means: "... then kill the Mushrikûn wherever you find them..."; Q.S. alTawbah [9]: 14 that says: "Fight against them so that Allah will punish them by your hands"; Q.S. al-Tawbah [9]: 36 that states: ".... And fight against the Mushrikûn collectively as they fight against you collectively. But know that Allah is with those who are al-Muttaqûn"; Q.S. al-Anfâl [8]: 39, which means: "And fight them until there is no more Fitnah (disbelief and polytheism) and the religion will all be for Allâh Alone."; and Q.S. alBaqarah [2]: 191 that states "And kill them wherever you find them".

\section{The Verses of Radicalism Justification: Fakhr al-Dîn al-Râzî’s Tafsîr bi al- $R a^{\prime} y \hat{\imath}$ Perspective}

Understanding the verses of Quran completely and comprehensively is the main objective of a field of study known as Tafsîr. It should be supported by the related sciences that have been formulated. The mastery of the variety of science is a requirement for a mufassir. However, those who are interested in tafsîr sometimes elaborate the understanding of the verses of the Quran based on the real masterpieces. The mufassirs' great classic and contemporary masterpieces have their distinct characteristics, which are

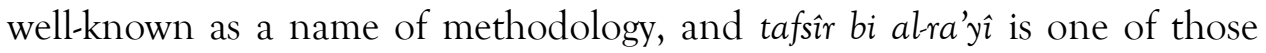
methodologies. The verses of the Quran that are used as the justification for radical actions ought to refer to the authoritative literatures regarding tafsîr to produce a more relevant point of view. Mafâtîh al-Ghayb is one of the literatures about tafsîr that is acknowledged by the world of Islam or Islamic 


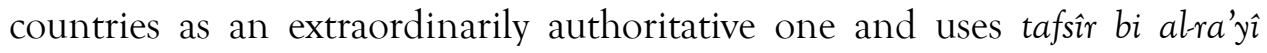
methodology.

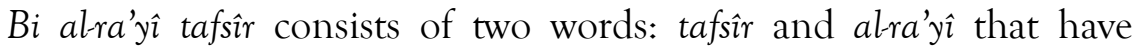
different meanings. In a simple concept, al-tafsîr is derived from the phrase fassara-yufassiru-tafsiran, but it has numerous meanings; those are al-ta'wîl, alkashf, al-sharh, al-bayân and al-îdâh. These various meanings can be understood in various words too, namely interpreting, revealing, explicating or explaining (Hamdan and Miski 2019, 251).

According to al-Zarqânî (d. $1367 \mathrm{H}$ ), the word al-ra'ŷ̀ is another meaning of alijtihâd (al-Zarqânî n.d., 49) that is simply understood as "opinion". Bi al-ra'yi tafsîr is simply defined as "the interpreter's belief when explaining the verses of the Quran based on his/her understanding and opinion, specifically and independently" (al-Qațân 2000, 362). In line with

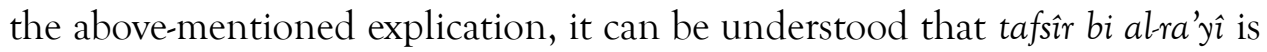
based on the interpreter's personal opinion. The thing to be highlighted is the matter that the personal opinion should be based on a mufassir's mastery of knowledge, abide the Islamic sharia, and avoid any evil and deviated interpretation (al-Zarqânî n.d., 49).

The debate about tafsîr bi al-ra'ŷ̉ among ulama (Islamic scholars)

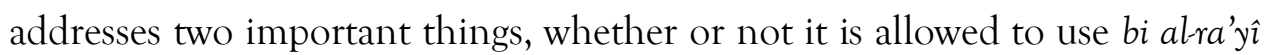
tafsîr in interpreting Quran. This debate is then narrowed down to the majority deal that is the approval to use tafsîr bi al-ra'ŷt for interpreting the Quran with tight interpretation requirements (al-Sâlih 2000, 292-3). This agreement is supported by concrete proofs such as familiar references in every era that are used by Muslim community like Mafâtîh al-Ghayb written by al-Râzî (d. $606 \mathrm{H})$ as the object of this writing, Anwâr al-Tanzîl wa Asrâr alTa'wîl written by al-Bayḍawî (d. $685 \mathrm{H}$ ), Madârik al-Tanzîl wa Haqâiq alTa'wîl written by al-Nasafî (d. $710 \mathrm{H})$, Lubâb al-Ta'wîl fî̀ Ma'ânî al-Tanzîl written by al-Khâzin $(\mathrm{d} .741 \mathrm{H})$ and Irshâd al'Aql al-Salìm written by Abû alSu'ûd (d. 982 H).

Fakhr al-Dîn al-Râzî has interpreted the verses of the Quran based on his ijtihâd (independent reasoning) as mentioned in his book entitled Mafâtîh al-Ghayb. The following is explication on his opinion and ijtihâd in interpreting the verses of the Quran concerning the verses that justify radical actions by using jihad as an excuse. The first was the words of Allah Almighty as found in surah al-Tawbah [9]: 5 "faqtulû al-mushrikina haythu wajadtumûhum". In explaining about the commands to fight against the 
kâfir/disbelievers, al-Râzî has previously mentioned the requirements as stated by the verse regarding the right time to execute a war. Al-Râzî quoted al-Laith' opinion that says "salakhtu al-shahra idhâ kharajtu minhu" interpreted as "I pass through the moon if I go out from it". Thus, according to al-Râzî, the basic meaning of "as-sulkhu" is "a term for the separation of something from its certain place". It can even be called as "the term for the separation of something from its certain time" caused by the strong correlation between the place and time (al-Râzî 1420 H, vol. 15, 528). The forbidden months that are mentioned in "al-ashhur al-hurum" is started from Nahâr day in Dhulhijjah month until the tenth day in Rabi' alAwal month by referring to the earlier verse that is "fasîh $\hat{u}$ fi al-ard arba'ata ashhur" (Q.S. al-Tawbah [9]: 2). After passing the months mentioned above, Allah allows four things, which are killing (fighting), arresting (capturing), embargoing, and spying.

Killing and fighting are two of the forbidden activities in the forbidden months mentioned above. This forbidden activity is categorized as haram to do and in other words it is reward to leave it and sinned to do it. However, after passing the forbidden months in carrying out these forbidden activities, it is possible to commit war activities or kill the enemy. In this case, al-Râzî quotes the word of Allah "waqtulûhum haythu wajadtumûhum", a command to absolutely fight or kill the enemy, whenever and wherever they are. Making the enemies of Allah as prisoners of war is the second choice if the enemy faced has been surrendered. Surrender means to put them as prisoners of war and then prisoners of war have their own rules of law and treatment. The third option given by the verse is an embargo. "Hișâr" in Indonesian is an embargo that is "prohibiting to go out of certain limits". "Wahsurhum" in this verse is the third choice made against the enemy to immediately force them to end the war. The fourth choice is to spy on the polytheists from the reconnaissance sites. "al-Marsad" is interpreted as "a place used to spy and monitor the enemy's movements".

The main target in the realization of four options and strategies above is essentially to repent as conveyed by the verse with His narration

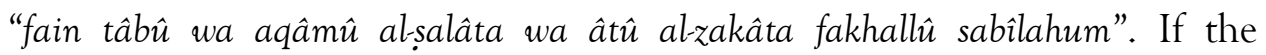
polytheists of Mecca repent by carrying out Allah's commands, which are praying and alms, then the four options will automatically be excluded. The exclusion of these four options is a concrete proof that Allah SWT, The One Almighty God who is Forgiving and very Merciful to His servants. 
The second verse used as a basis for jihad is Q.S. al-Tawbah [9]: 14 "qâtilûhum yu'adhdhibuhum Allâh biaydîkum". Al-Râzî said that in this verse Allah again repeats "the command to fight" (al-Râzî 1420 H, vol. 16, 5) while mentioning the five advantages and benefits of carrying it out. Allah uses the term "punishment" in this verse which can be understood as "torture" to imply the real reality that "punishment" will be given to unbelievers; through His will, it can happen in the world, and it can also be reversed in the hereafter.

The punishment referred to in this verse could be three possibilities: be killed, be captured or lose a property. Moreover, this punishment can be accepted in two or three kinds at one time. Al-Râzî also conveyed the reality of belief in looking at the sentence yu'adhdhibihim Allâh biaydî al-mukminîn that "if it is possible to say the unbelievers are punished through the hands of believers, then it may also say otherwise that the believers are punished through the hands of unbelievers. It may also be analogous by saying that the Prophet was verbally denied by unbelievers, while believers were cursed verbally by unbelievers". It is due to the fact and reality of nature that Allah created the actions of a servant. When it is not allowed to say and believe as narrated above, according to al-Râzî, it is understood that Allah did not create all the actions of His creatures, but still rely on Him as a way to expand. It is because they accept all His commands and tenderness, as well as the actions in the form of all obedience to Him (al-Râzî 1420 H, vol. 16, $6-8)$.

The third verse as the basis of the truth argument for radical actions under the pretext of jihad is Q.S. al-Tawbah [9]: 36, "waqâtilu al-mushrikina kâffatan kamâ yuqâtilûnakum kâffatan". Al-Râzî explains his opinion in interpreting the command of war in this verse which contained in the text waqâtilû al-mushrikîna kâffatan translated with "and fights the polytheists as a whole”. Al-Râzî does not discuss the phrase al-mushrikîn in this verse, because the phrase al-mushrikin is is already understood in such a way that they are residents of Mecca in the era of the Prophet who are believed as idol worshipers that we know today with the term "animism". Al-Râzî seems to focus on the phrase "kâffah" by saying his tendency to the opinion that the meaning of "kâffah" is "to fight them as a whole as they also fight the Muslims as a whole". Allah commands to fight the enemy as a whole by helping each other, hand in hand and cooperation. Allah does not allow fighting the polytheists in the opposite way that is to let each other, break 
away and be selfish by prioritizing each other's personal safety. Al-Râzî also asserted that the narration of the verse with the word "kâffah" is a sign that it is possible to fight these polytheists throughout the entire month without looking at the term of it is haram month or not (al-Râzî 1420 H, vol. 16, 44).

The fourth verse is Q.S. al-Anfâl [8]: 39, "waqâtilûhum hattâ lâ takûna fitnah wayakûna al-dînu kulluhî lillâh". The unbelievers, according to al-Râzî, if they come out from their disbelief, then they will obtain forgiveness from Allah, The God Almighty. Still, if they return to their disbelief, then they will be fought. "al-Fitnah" in this verse refers to the psychological and sociological condition of the Prophet's companions who just converted to Islam. The Prophet's companions at that time believed and held firm this religion. Their companions were very much taking care of the brotherhood more than in their pre-Islamic era until the Prophet commanded some companions to emigrate to Habsyah.

There is a second opinion which explains that when some Ansar people did bay'at/state their trust towards the Prophet in Bayt 'Aqabah, the Quraysh in Mecca tried to estrange them from this religion. They did it in various ways such as intimidation, provocation and even physical actions until the companions experienced a terrible trouble at the time. Allah then commanded to fight against the Quraysh, this polytheistic community to eliminate the intended defamation (al-Râzî 1420 H, vol. 15, 483). Al-Râzî expresses his opinion on this defamation by saying that the quality and quantity of companions in love for Islam is more reliable than the love of their own lives. While on the other hand, the unbelievers work hard at hurting believers and instilling doubt and confronting them with trouble and hardship. In the event of a war, which ended with victory in the ranks of the Muslims, the defamation will be vanished entirely from Islam itself (al-Râzî 1420 H, vol. 15, 483).

The fifth verse of Q.S. al-Baqarah [2]: 191, "waqtulûhum haythu thaqiftumûhum wa'akhrijûhum min ḥaythu akhrajûkum wa al-fitnatu ashaddu min al-qatl". Al-Râzî says that this verse is specifically meant for the Prophet Muhammad and his companions. They participated in the pilgrimage, while it is generally addressed to every Muslim whenever and wherever they are. Two commandments were given to the Prophet Muhammad as the leader and the Muslim (the companions) at that time, who was fighting against the unbelievers of Mecca and was also expelling them from their 
homes and the city of Mecca in general. Therefore, the history records how the Prophet Muhammad emptied the forbidden land of Mecca from the polytheists, as well as the banned area of Medina.

The community of the people commanded to be fought in this verse were the unbelievers who lived in the city of Mecca. They were also called the Quraysh polytheists community. This verse commands to fight them in the permitted or forbidden situation or the forbidden months. The offensive action was carried out on the strict condition that must be preceded by the war committed by Mecca's polytheists against the Prophet Muhammad and his followers from the companions (al-Râzî $1420 \mathrm{H}$, vol. 15, 483). The second action was the expulsion committed by the unbelievers to the Muslims (the companions) which the Quran discusses with the narration of wa'akhrijûhum min haythu akhrajûkum. al-Ikhrâj in this verse contains two insights: first, forcing them (the companions) to come out compulsively; and second, commit intimidation and terror that endanger to choose the option to abstain (al-Râzî 1420 H, vol. 15, 290).

The word haythu in this verse contains two meanings that are the turning point of the expulsion, which is the city of Mecca and also their (the companion's) residences. The city of Mecca once became the center of activity of the cross-tribe Arabian. There were houses inhabited by the entire citizen, some of whom had converted to Islam and some were still unbelievers (polytheists). The defamation according to al-Râzî is the name of an activity that causes a test (al-Râzî $1420 \mathrm{H}$, vol. 15, 290). The first action committed by the unbelievers was the intimidation of terror toward the companions and other radical activities which led to a group of the companions evacuated and left their families and homeland to a safe place. The reality was to avoid the disbelief of the unbelievers and sincerely let themselves off of the fact that they are afraid and worried about. The companions' defensive actions in this escape were recognized as extraordinary defamation beyond the act of assassination. Al-Râzî made an analogous of the defamation mentioned in this verse with a contemptible punishment for disbelief. In his opinion, creating an analogous of the defamation with the punishment is allowed.

It seems that the interpretation of bi al-ra'yî by Fakhr al-Dîn al-Râzî in elaborating the Quranic verses used as a basis for radical action in the face of the jihad. Fakhr al-Dîn al-Râzís view through his book of interpretation Mafâtîh al-Ghayb can be used as a reference and basis solution to the complex and multidisciplinary problems of the Quranic 
interpretation. Furthermore, the tafsîr bi al-ra'ŷ̉ as a methodology can be used as a solution and alternative to the need for verse interpretation of the Quran amidst the various problems of people.

\section{Conclusion}

There are five verses of the Quran used as arguments for justification for radical actions with the message of jihad that is Q.S. alTawbah [9]: 5 which means: "...kill the polytheists wherever you find them...". Q.S. al-Tawbah [9]: 14 says: "fight them; Allah will punish them by your hands". Q.S. al-Tawbah [9]: 36 which means: "and fight against the unbelievers collectively as they fight against you collectively. And know that Allah is with the righteous [who fear Him]". Q.S. al-Anfal [8]: 39 which means: "And fight them until there is no defamation and [until] the religion, all of it, is for Allah". Q.S. al-Baqarah [2]: 191 means: "and kill them wherever you overtake them". These verses are understood textually, through translation and not by authoritative literary interpretations such as the one written by al-Râzî in his Mafâtîh al-Ghayb.

It seems that Imam Samudra took only a few sentences of the translation, which led to a bombastic understanding of the Q.S. al-Tawbah [9]: 5. Al-Râzî interpreted this verse by first clarifying the conditions of the ability to raise a weapon, in the sense of war or killing, and then to bring about a similar action, but still offers the option of forgiveness if the enemy has repented. In Q.S. al-Tawbah [9]: 14, Imam Samudra also just cut out a few sentences altogether. Al-Râzî looks at the verse intimately and further argues that killing in the form of punishment in three possibilities, which are executed, be captured or lose the property and all three of them at once. This term of punishment, according to al-Râzî, can also be obtained by the unbelievers through the hands of the believers and vice versa.

While the Q.S. al-Tawbah [9]: 36 is interpreted by al-Râzî by highlighting the word kaffah, which is to fight the whole way through mutual support, to help one another and to help each other and not to let each other. The object of the battle was the polytheists of Mecca. A few sentences in Q.S. Anfâl [8]: 39 are also the arguments of Imam Samudra. Al-Râzî looks at this verse by explaining that the war was carried out to avoid defamation in the form of intimidation, provocation or open war committed by the polytheists of Mecca against the Prophet and his companions. Al-Râzî also looked at Q.S. al-Baqarah [2]: 191 as a form of command to act under the means of combating and expelling. The eviction 
was carried out from their homes to all over the city. This offensive action is compatible to the previous action.

\section{References}

Abdillah, Junaidi. 2014. "Radikalisme Agama: Dekonstruksi Ayat-ayat "Kekerasan” Dalam al-Qur'an." Kalam: Jurnal Studi Agama dan Pemikiran Islam 8(2): 281-99.

DOI: https://doi.org/10.24042/klm.v8i2.224

Azhari, Muhammad. 2013. "Konsep Pendidikan Sains Menurut al-Râzî (Telaah terhadap Tafsir Mafâtîh al-Ghayb)." Jurnal Ilmiah Islam Futura 13(1): 43-57.

DOI: http://dx.doi.org/10.22373/jiif.v13i1.571

al-'Asqalanî, Aḥmad ibn 'Alî ibn Hajar. 1379 H. Fath al-Bârî Sharh Ṣahîh alBukhârî, ed. Muhammad Fu'âd 'Abd al-Bâqî. Beirut: Dâr al-Ma'rifah. al-Badaniyyah, Dhiyab, and Khoulah al-Ḥasan. 2017. "Naḥwa Takâmul Ithna "Ashara Anmudhajan Naẓarian fî Tafsîr al-Taṭarruf: alAnmûdhaj fî al-Tatarruf.” Majallat al-Dirâsât wa al-Abhâth 26: 3-6.

al-Bahûṭ̂, Manșûr ibn Yûnus ibn Ṣalâh. 1983. Kashâf al-Qinâ' 'an Matn alIqnâ'. Beirut: Dâr al-Kutub al-'Ilmiyyah.

Bamakhramah, al-Tâib ibn 'Abd Allâh. 1428 H. Qilâdah al-Nahr fî wa Fayât A'yân al-Dahr. Jeddah: Dâr al-Manhaj.

al-Bukhârî, Muhammad ibn Ismâ'îl. 1422 H. al-Jâmi' al-Musnad al-Sahih. Dâr Ṭûq al-Najât.

al-Hamawî, Yâqût ibn 'Abd Allâh. 1414 H. Mu'jam al-Udabâ - Irshâd alAryab ilâ Ma'rifat al-Adîb. Beirut: Dâr al-Gharbî al-Islâmî.

Hamdan, Ali, and Miski Miski. 2019. "Dimensi Sosial atas Tafsir Audiovisual.” Religia: Jurnal Ilmu-Ilmu Keislaman 22(2): 248-66.

DOI: https://doi.org/10.28918/religia.v22i2.2190

al-Hurânî, Taqî al-Dîn Ibn Taymiyah. 1987. al-Fatâwâ al-Kubrâ. Beirut: Dâr al-Kutub al-'Ilmiyyah.

Ibn Hazm, 'Alî ibn Sa'îd. n.d. al-Faṣl fì al-Milal wa al-Ahwâ' wa a-Nahl. Cairo: Maktabah al-Khanjî. 
Ibn Khallikân, Shams al-Dîn Aḥmad. 1904. Wafyât al-A'yân wa Anbâi Abnâi al-Zamân. Beirut: Dâr al-Sâdir.

Jalaluddin, Abd. 2018. "Ketenangan Jiwa Menurut Fakhr al-Dîn al-Razî dalam Tafsîr Mafâtîh al-Ghayb.” Al-Bayan: Jurnal Studi al-Qur'an dan Tafsir 3(1): 36-50.

DOI: https://doi.org/10.15575/al-bayan.v3i1.2288

Jamil, Nasir. 2005. Membongkar Jamaah Islamiyyah: Pengakuan Mantan Anggota JI. Jakarta: Grafindo.

Dinas Pendidikan. 1990. KBBI (Kamus Besar Bahasa Indonesia). Jakarta: Balai Pustaka.

Khairunnisa, Siti, Lukman Zain, and Anisatun Muthiah. 2016. "Penafsiran Ayat-ayat Pemicu Radikalisme Perspektif Ibn Taimiah dan Quraish Shihab (Telah Q.S At-Taubah (9): 5 dan 29)". Jurnal Diya al-Afkar 4(02): 85-106.

DOI: http://dx.doi.org/10.24235/diyaafkar.v4i02.1149

Khalid, Anas Shafwan. 2018. "Metodologi Tafsir Fakhr al-Din al-Razi: Telaah Tafsîr QS. Al-Fatihah dalam Mafatih al-Ghayb.” Al-Tadabbur: Jurnal Ilmu al-Qur'an dan Tafsir 3(1): 97-115.

Mahmud, Mani'. 2006. Metodologi Tafsir (Kajian Komprehensif Metode Para Tafsir). Jakarta. PT. Raja Grafindo Persada.

Nasr, Seyyed Hossein. 2003. The Hearth of Islam: Pesan-pesan Universal Islam untuk Kemanusiaan. Trans. Nurasiyah Fakih Sutan Harahap. Bandung: Mizan.

Nizar, Coirun. 2015. "Kontekstualisasi Jihad Perspektif Ke-Indonesia-an." Ulul Albab: Jurnal Studi Islam 16(1): 21-44.

DOI: http://dx.doi.org/10.18860/ua.v16i1.2784

Nuwayhaḍ, Âdil. 1409 H. Mu'jam al-Mufassirîn min Șadr al-Islâm wa hattâ al'Așr al-Hâdir. Beirut: Mu'assasah Nuwayhaḍ al-Thaqâfiyyah li alTaklîf wa al-Tarjamah wa al-Nashr.

al-Qatțan, Mannâ' Khalîl. 2000. Mabâhith fî 'Ulûm al-Qur'ân. Riyad: Maktabah al-Ma'ârif li al-Nashr wa al-Tawzî̀. 
al-Qurțubî, Muhammad ibn Aḥmad ibn Abî Bakr. 1964. al-Jâmi' li Ahkâm alQur'ân, ed. Ahmmad al-Bardunî and Ibrâhîm Ațfish. Cairo: Dâr alKutub al-Mișriyyah.

al-Râzî, Muhammad ibn 'Umar Fakhr al-Dîn. 1420 H. Mafâtîh al-Ghayb. Beirut: Dâr Ihyâ’ al-Turâth al-'Arabî.

Rodin, Dede. 2016. "Islam dan Radikalisme: Telaah Atas Ayat-ayat "Kekerasan" dalam Al-Quran”. ADDIN: Media Dialektika Ilmu Islam 10(1): 29-57.

DOI: http://dx.doi.org/10.21043/addin.v10i1.1128

Roys, David, Simon W. Lewis, and Amelia M. Taylor. 2005. "A Case Study in Forensic Chemistry: The Bali Bombings." Talanta 67: 262-8.

DOI: http://dx.doi.org/10.1016/j.talanta.2005.03.026

al-Ṣâlih, Subhị̂. 2000. Mabâhith fì 'Ulûm al-Qur'ân. Beirut: Dâr al-'Ilm li alMalâyîn

Samudra, Imam. 2004. Aku Melawan Teroris. Solo: Jazeera.

al-Shaybânî, Aḥmad ibn Muhammad ibn Hanbal. n.d. Musnad. Cairo: Dâr al-Hadith

al-Subkî, Tâj al-Dîn ibn 'Abd al-Wahhâb ibn Taqî al-Dîn. 1413 H. Tabaqât al-Shâfi'tiyyah Kubrâ. Beirut: Hijr li al-Tibâ'ah wa al-Nashr wa alTawzî̀.

Umam, Fawaizul. 2019. "Ideological Involution of The Islamists." Ulul Albab: Jurnal Studi Islam 20(1): 25-45.

DOI: http://dx.doi.org/10.18860/ua.v20i1.5714

Zada, Khamami. 2011. Islam Radikal Ormas-ormas Islam Garis Keras di Indonesia. Jakarta: Teraju.

al-Zarqânî, 'Abd al-Aẓîm. 1367 H. Manâhil al-Irfân fî̀ 'Ulûm al-Qur'ân. Cairo: Matba'ah 'Isha al-Bâbî al-Halabî.

al-Ziriklî, Khayr al-Dîn ibn Mahmûd. 2002. al-A'lâm. Beirut: Dâr al-'Ilm li alMalâyîn. 